\title{
IMPROVING LEARNING IN A TRADITIONAL, LARGE-SCALE SCIENCE MODULE WITH A SIMPLE AND EFFICIENT LEARNING DESIGN
}

\author{
Mikkel Godsk. [godsk@cse.au.dk], Aarbus University [http:/ / mww.au.dk], \\ C. F. Mollers Allé 8, DK-8000 Aarbus C, Denmark.
}

\begin{abstract}
This article presents the experiences and results of using a simple learning design for transforming a traditional, large-scale, face-to-face science module in calculus into blended learning where all face-to-face lectures were replaced by webcasts and online activities. The article presents the impact on teaching and learning in terms of how the teacher and the students used the materials and the impact on the students' performance and satisfaction. The article concludes that replacing face-to-face lectures with webcasts and online activities has the potential to improve learning in terms of a better student performance, higher student satisfaction, and a higher degree of flexibility for the students. In addition, the article discusses implications of using learning design for educational development, how learning design may help breaking with the perception that facilitating blended learning is a daunting process, and, ultimately, its potential for addressing some of the grand challenges in science education and the political agenda of today.
\end{abstract}

Keywords: Blended learning, learning design, science education, learning pathways, video, Justin-Time Teaching, efficiency

\section{Background}

Today's political agenda for higher education is rather universal: it is essential that a higher share of future generations obtain a higher level of education in order to ensure prosperity and economic growth in society. In Denmark the current political agenda on education is expressed in a national strategy and a so-called 'profile model' (The Danish Government, 2012; The Danish Ministry of Education, 2014a; 2014b). The strategy and model states that $95 \%$ of future cohorts must complete an upper secondary education such as GCSE by 2015, 60\% must complete a further education such as academy and professional bachelor programmes, and 25\% a higher education such as Master's programmes or other university degrees by 2020 (The Danish Government, 2012, p.7). At the same time the political agenda is challenged by limited budgets, the financial crisis, and the costs for providing education to these large shares of future generations.

In addition, a recent issue of Science has drawn attention to what it refers to as the 'Grand Challenges in Science Education' (Hines et al., 2013). The issue identifies 20 challenges and a series of issues and topics that need to be addressed in order to ensure quality and effectiveness of science teaching. The topics include systematic teacher training and pedagogical development for educational technology, more flexible and student-centred learning, an improvement of student motivation, and, not least, well-informed decision-making and consideration of the costeffectiveness of pedagogical reforms (ibid.). 
Neither the 'profile model' nor the recent issue of Science provide direct solutions to the challenges but since the late 1980s various studies have shown that educational technology has the potential to improve teaching and learning in higher education in terms of providing higher flexibility in time, place, and pace for the students, increase students' satisfaction and motivation, and in some cases even to act as catalyst for deep learning and better examination results (Blumenfeld et al., 1991; Conole, 2013; Conole \& Dyke, 2004; Price \& Kirkwood, 2011). Unfortunately, the development and implementation of effective technology-enhanced learning oftentimes requires large budgets, expertise from educational developers and media producers, and particularly enthusiastic teachers. This increases the complexity as well as the amount of effort required to effectively implement technology in specific modules and to adapt to various educational contexts making ad hoc solutions unfeasible and the design process daunting (Earle, 2002; Conole, 2013; Garrison \& Kanuka, 2004; Romiszowski, 2004; Weller, 2002). Consequently, a more efficient solution has to be found where the use of technology is cost-effective, supported by the institution through policies, funding, and pedagogical expertise, practical to the teachers, and, ideally, improves students' learning at the same time (Godsk, 2014).

A possible solution is to adapt a learning design approach and use its models and other kinds of resources for guiding the development of blended and online learning. Learning design has demonstrated its potential for minimising the complexity and required effort for teachers in developing theoretically informed teaching practice (Britain, 2004; Conole et al., 2004; Conole \& Fill, 2005; Conole \& Oliver, 2002; Cross \& Conole, 2009); however, the design would also need to be cost-effective and/or reusable in order to address the political agenda. This leads to an interest in simple and efficient learning design (cf. Godsk, 2014). Learning design models and tools take many shapes, can be more or less concrete, and may be aimed at specific subject areas, educational levels and settings (Conole \& Oliver, 2002).

This article describes how a simple learning design was used to transform the face-to-face lectures into webcasts and online activities in a large-scale science module and present its impact on teaching and learning. The results suggest that a simple design can be used to transform traditional science teaching into active, more flexible and satisfactory online learning efficiently. Thus, learning design may potentially be a part of the solution to some of the grand challenges in science education while also addressing the political agenda.

\section{Technology-Enhanced and Blended Learning at Aarhus University}

Aarhus University (AU) is a traditional, campus-based university where most of the teaching is organised as face-to-face lectures, face-to-face exercises, other kinds of in-class teaching activities, and homework. However, AU, as well as many other universities, has an ambition to continuously develop and improve learning by means of up-to-date educational technologies for teaching and learning and pedagogical (and technical) assistance to the teachers and students explicated in institutional policies and strategies (Aarhus Universitet, 2011). In the policy of educational IT' at AU the stated objective is that $60 \%$ of all teachers should receive an offer for 'rethinking assistance' by February 1st 2015 (ibid.), and recently the pro vice-chancellor announced that the study environment should be improved by making good use of technology (Correll, 2014). It is up to each of the four faculties and their educational units to allocate funding and choose the most appropriate implementation strategy, and due to a minimal budget at the Faculty of Science and Technology, there has been a special interest in focusing on blended and online learning initiatives with a genuine need and clear incentives for technology-enhancement, providing blended learning, and/or with a potential large impact in terms of number of students and teachers affected by the initiative. As a consequence the educational unit gave priority to transforming Calculus 2. 


\section{Transforming Calculus 2}

Calculus 2 is a compulsory undergraduate first-year module on all science programmes at the university. The incentives for transforming the module were first and foremost the department management's desire to make the teaching more cost-effective by reducing the required teaching staff for the module by developing reusable, web-based teaching materials, and, at the same time, use the technology to modernise the teaching practice and improve learning. The main learning goal of the module is to provide an introduction to the theory of how to differentiate and integrate functions of one or several variables ... linear algebra, and infinite series' (Course Catalogue, 2013). The module counts for 5 ECTS and is compulsory for students studying Mathematics and Mathematics-Economics, and a compulsory auxiliary module for the other 11 undergraduate science programmes. This makes Calculus 2, together with its predecessor Calculus 1, one of the largest modules in terms of enrolled students at the faculty. Normally, the module is taught face-to-face over 7 weeks with 4 hours of lectures, 2 hours of exercises with written assignments, and 3 hours in the Mathematical Lab. The examination is summative and consists of a 4 hour written examination on a set topic and assessed by the Danish 7-point grading scale. In order to be eligible to take the examination the student must pass 4 of the written assignments during the module (ibid.).

In this case a total of 1,184 students deriving from all 13 science programmes at the faculty were enrolled in the module except the engineering programmes, since they run their own calculus modules. The average age of the responding students was 21.9 years (median 21 years) and 50\% were female. Most students live relatively close to campus and their average distance to the university was 13.2 kilometres; however, the median was merely 5 kilometres and $75 \%$ lived less than 10 kilometres away.

In order to actualise the aforementioned incentives, the teacher and management had previously been working on some ideas about how the materials should be designed and the teaching carried out. These ideas primarily entailed a transformation of the face-to-face lectures into online learning in terms of screencasts presenting the curriculum and exercises in form of multiple choice quizzes (MCQs) for testing students' understanding. The ideas had been tried out during an earlier run of a calculus module (in 2012) by transforming a single lecture into an online, sequential learning path (also referred to as 'learning pathway') shifting between screencasts and MCQs. Inspired by the positive experiences from this run and in order to operationalise and theory-inform future technology-enhancements and transformations the educational unit developed a learning design model, 'STREAM' (Godsk, 2013), based on the ideas of Active Learning (Bonwell \& Eison, 1991), Just-in-Time Teaching (Novak et al., 1999), and Peer Instruction and Flipped Classroom (Mazur \& Hilborn, 1997). The management and teacher decided to use a similar design to transform the entire Calculus 2 module and, in dialogue with an educational developer and the media lab, the relevant materials and activities were developed and implemented.

\section{Methodology}

The transformation of the module was evaluated experimentally with a post test-only design (cf. Creswell, 2014) and by means a web-based questionnaire, examination results, statistical data, evaluation results, and interviews. The students were divided into four major groups (so-called 'tracks'): Track 1 (or 'T1') was the test group where the lectures were transformed into online learning and Track 2-4 ('T2-4') constituted the control group receiving traditional face-to-face lectures. 306 of the students (equivalent to $26 \%$ ) followed T1. The division into tracks was made by the study administration solely by taking two practical factors into consideration: the different study programmes' syllabus and in consideration for the existing exercise group structure. Besides 
this the division was completely random. T1 consisted of a total of 135 Mathematics students, 171 Physics students, 60 Molecular Medicine students, and 42 Chemistry students. T2-4 consisted of students from most science programmes except Mathematics and Molecular Medicine, but did include the Mathematics-Economics students. This means that both T1 and T2-4 consisted of groups of students to whom the module was classified as a compulsory module and as a compulsory auxiliary module; however, the percentage of students assumed to perform well in this module is relatively higher in T1. In addition, some students decided to switch to T1 during the module. These students were considered as a secondary test group and treated separately in this study under the designation 'T1s'. Four respondents were not in a group and therefore not included in the results. One respondent decided to switch from T1 to T2-4.

\section{Studies and Data}

In order to evaluate the impact on teaching and students' learning various data was collected and a series of qualitative and quantitative studies were carried out. This included:

- A web-based questionnaire addressing the students' profile, usage of the materials, satisfaction, and learning approach. The questionnaire was sent to all students immediately after the examination (i.e. Jan. 18th 2014) and reminders were sent after 10 days to the students, who had not responded yet. The questionnaire was closed after 3 weeks (i.e. Feb. 8th) with a response rate of $26 \%$ fully completed $(n=307)$ and $1 \%$ partly completed $(\mathrm{n}=14)$. As announced to the students, the responses were treated anonymously so that no data would be made available which could identify the identity of individual or small groups of students. All study programmes that require students to take the module were represented in the responses.

- The examination results for each individual student including all the respondents. The exams were graded according to the Danish 7-step scale (which is compatible with the ECTS-scale). The scale consists of two failing grades, $-3(\mathrm{~F})$ and $00(\mathrm{Fx})$, and five passing grades, $02(\mathrm{E}), 4(\mathrm{D}), 7$ (C), 10 (B), and 12 (A). Grades as of 7 are considered to be above average.

- Statistical and access data from the IT systems involved. This includes the play statistics from the video server and access and usage statistics of the module homepage in the learning management system (LMS).

- An interview with the module secretary about the organisation of the module.

- An interview with the teacher about the background for the transformation, how the preparations and teaching were carried out, and his experiences with teaching with technology.

- Registration of the time spent on developing the online materials and data about costs.

- Examination results from previous years.

Some of these studies and data contain certain threats to validity, biases, and additional uncertainties that should be taken into account. These include:

- The representativeness of the web-based survey responses. Though the $26 \%$ response rate of the survey is potentially equivalent to a sampling error of less than $5 \%$ with a confidence level of $95 \%$, some students may have been specially motivated to respond due to strong opinions about the use of technology or a disappointing examination result. Furthermore, active students obtaining good examination results may also be more active in responding to surveys.

- The risk of the Hawthorne (or 'observer') effect. As the test group inevitably will be aware that the online learning is a different setting than the face-to-face lectures there is a risk of change in behaviour and/or effort. However, the change in student behaviour can 
be considered as a natural and non-persistent outcome of transforming learning and, furthermore, studies suggest that actual impact of the effect is insignificant (Brown, 1992; Jones, 1992).

- The representativeness of the control group. The control group (T2-4) has a slightly different composition than the test group (T1) and, in addition, some students left the group for the secondary test group T1s. Both facts lower the representativity; however, to partly compensate for this, additional figures, which deduct the results from the students enrolled with Calculus 2 as compulsory module and the GPAs of the entire T1 and T2-4 groups (including T1s) of students, are provided in the results.

- The differences in the actual teaching on the different tracks. Though the curriculum and the overall module structure were the same, there were differences in teacher, materials used in the lectures, and how the teacher would teach. However, the premise in this study is that there is a difference in the way the curriculum is being taught.

- An interest in obtaining a good result that may be reflected in the interview with the teacher.

- Various bad (or good) experiences with IT systems, network problems, etc. among the test group, which may have influenced the over-all learning experience.

- A picture perfect perception of face-to-face lectures among the test group, which may have caused a biased view on the online lectures.

- Minor differences in the size of the population (n) due to procedure differences in obtaining data from different administrative systems.

\section{Impact on Teaching}

The actualised design was guided by the STREAM model and consisted of a complete transformation of all face-to-face lectures into a series of streaming, dual-channel, webcasts, i.e. a video channel of the presentation and another of the teacher, of typically 10-20 minutes supplemented with one or more subsequent MCQ exercises for the student to test his/her understanding of the webcast and open-ended questions for reflection and follow-up. The webcasts were recorded directly to a streaming server using a LifeSize video conferencing system combined with a LifeSize video centre. The materials were compiled and structured in a series of online, sequential learning paths in the LMS (i.e. Dokeos 1.8.4) for asynchronous usage with a section available for each week (see example in Figure 1) and supplemented with two optional 'Lecture Mathematical Lab' face-to-face sessions of two hours each week allowing the students to drop-in, watch the webcasts together, and ask the teacher questions. In practice this lead to the transformation of 7 weeks of $2 \times 2$-hour lectures into 14 learning paths of each 10-12 webcasts and 4-16 MCQs. 


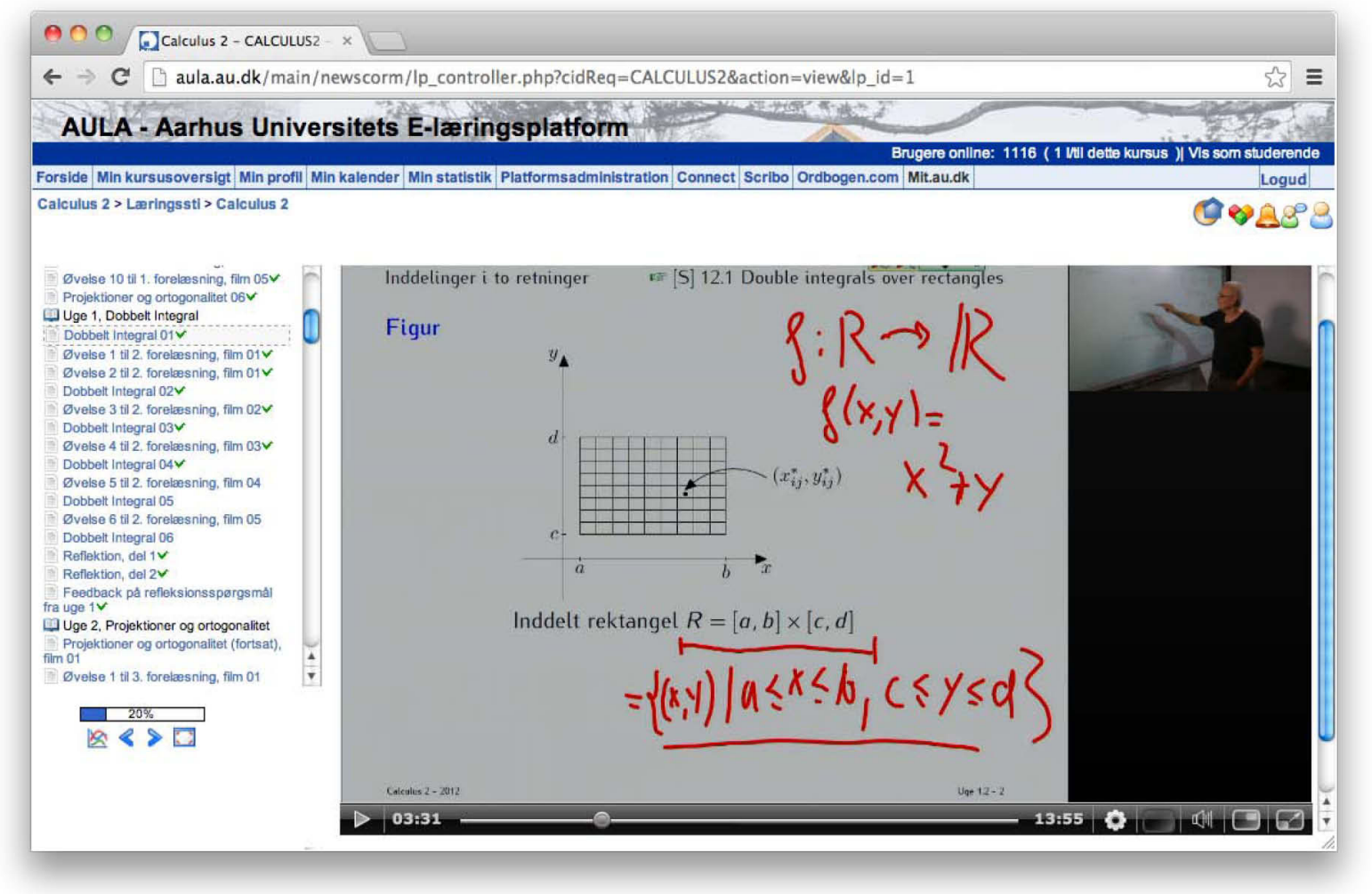

Figure 1. The learning design of the transformed lectures. The figure shows a learning path in the LMS containing webcasts, MCQs, and reflection exercises with follow-up. The student can navigate the path using the left menu.

The open-ended questions for reflection were formulated according to the principles of 'warmup exercises’ known from Just-in-Time Teaching (cf. Novak et al., 1999; Simkins \& Maier, 2010) asking about what the student found confusing or interesting. A tutor from the existing tutor team was recruited as 'e-instructor' and each week she would browse through all the incoming reflections and develop supplemental, follow-up learning materials to address the most pertinent and critical subjects. These follow-up materials took different forms such as short webcasts with additional worked examples or other kinds of relevant materials followed by a notification email sent to the students each week.

The students did not receive any detailed introduction to the materials except a one-minute introductory video in the first learning path, which provided a loose idea about the how the webcasts could be used for studying and group discussions. The students were notified about the webcasts in the first weekly assignments note; however, as the teacher revealed in the subsequent interview there was an actual risk that not all students were aware of the existence of the learning paths. Furthermore, the students were rather inexperienced with this kind of learning and $76 \%$ of the students in the test group responded that they had no previous first-hand experience with or knowledge of teaching making use of online learning paths with activities.

The teacher had been very cautious not to change any of the other teaching activities besides the lectures: '.. one of the virtues with what we did here was that we only tampered with one aspect. So the module has not been changed at all except for using these videos on one quarter of the students' (teacher on the module, translated from Danish). I.e. the exercises with written assignments, the Mathematical Lab sessions, and the examination remained unchanged and, to his knowledge, no references were made to the online materials from any of these activities. A few students decided to use the learning paths during the Mathematical Lab sessions; however, it 
was the teacher's impression that the students disturbed each other. The supplemental and optional Lecture Mathematical Lab sessions offered to the T1 students were little used. According to the teacher the number of participants dropped 'exponentially' during the module from approximately 95 students attending the first session to 5 students the last session.

The teacher responded in the interview that his preparations had been very different than usual. Usually, he would prepare just prior to the lectures by reading textbooks and preparing clicker questions. For the transformed lectures he prepared the teaching over a longer period of time and estimated to have spent approximately $1 / 3$ more time for preparations on the whole. He spent most of the time preparing the materials for the webcasts, preparing the presentations, and making the actual recordings. Several lectures were recorded on a single day and prepared just prior to the recording; however, the materials had been prepared longer time in advance and partly based on PDF-slides already developed by a colleague. The teacher compared the effort to preparing for teaching a new module: 'if I am going to teach a new module, which I haven't taught before, I also have to read the book and/or the teaching material, which I have to base it on. So, you can say, what I did with those files (i.e. the preparation of the presentation materials) equals this' (teacher on the module, translated from Danish).

In the interview, the teacher expressed excitement about the transformation and appreciation of the collaboration with the educational developer and the media lab. However, he also felt restricted by not having the technical skills to set up the learning paths himself. He was surprised to discover that the students preferred to see the webcasts at home instead of attending the Lecture Mathematical Lab sessions.

The variable costs for developing and implementing the materials and for e-instructor assistance were approximately 6,000 EUR in total, which equals 5 EUR per student for the initial run of the module. In addition, the fixed costs for running the media lab and the educational unit should be taken into account. If the materials are reused for a later run of the module with only minor changes the variable costs, including an e-instructor, can be estimated to approximately 1,000 EUR in total or 1 EUR per student.

\section{Impact on Students' Learning}

The impact on students' learning was assessed through an analysis of how the materials were perceived and used by the students including the flexibility the materials provided, the students' actual performance, and their satisfaction with the teaching. 


\section{Use of Materials and Flexibility}

Knowledge about the usage of the learning paths was identified based on statistics from the LMS (cf. Table 1).

Table 1: The number and usage of the learning paths, webcasts, and exercises

\begin{tabular}{|c|c|c|c|c|c|c|c|c|}
\hline Materials & Week 1 & Week 2 & Week 3 & Week 4 & Week 5 & Week 6 & Week 7 & Total \\
\hline $\begin{array}{l}\text { Number of learning } \\
\text { paths }\end{array}$ & 2 & 2 & 2 & 2 & 2 & 2 & 2 & 14 \\
\hline Number of webcasts & $\begin{array}{l}12 \\
(+1 \text { intro } \\
\text { video })\end{array}$ & 11 & 10 & 12 & 12 & 10 & 12 & 79 \\
\hline Number of MCQs & 16 & 10 & 9 & 10 & 10 & 7 & 4 & 66 \\
\hline Follow-up materials & $\begin{array}{l}2 \text { webcasts } \\
\text { with worked } \\
\text { examples }\end{array}$ & $\begin{array}{l}\text { Individual } \\
\text { feedback }\end{array}$ & $\begin{array}{l}2 \text { documents } \\
\text { with } \\
\text { mathematical } \\
\text { proofs }\end{array}$ & $\begin{array}{l}2 \text { webcasts } \\
\text { with worked } \\
\text { examples }\end{array}$ & $\begin{array}{l}1 \text { PDF } \\
\text { document } \\
\text { with a } \\
\text { collection of } \\
\text { theorems }\end{array}$ & $\begin{array}{l}2 \text { tablet } \\
\text { videos }+1 \\
\text { webcast }\end{array}$ & - & $\begin{array}{l}7 \text { webcasts } \\
\text { and tablet } \\
\text { videos }+3 \\
\text { documents }\end{array}$ \\
\hline \multicolumn{9}{|l|}{ Usage } \\
\hline Webcast plays & 355 & 295 & 305 & 278 & 253 & 252 & 270 & 287 \\
\hline $\begin{array}{l}\text { Number of student } \\
\text { reflections }\end{array}$ & 54 & 30 & 27 & 24 & 18 & 18 & $\mathrm{n} / \mathrm{a}$ & 171 \\
\hline
\end{tabular}

Furthermore, the questionnaire revealed that the extent of the students' usage of the learning paths highly differs. On average, the T1 students completed 11.1 learning paths (of 14) and saw each webcast once. The majority of the students (81\%) participated in the MCQs and a smaller part in the reflection exercises $(39 \%)$ or saw the follow-up materials $(45 \%)$.

MCQ exercises

Reflection exercises

Follow-up materials and videos

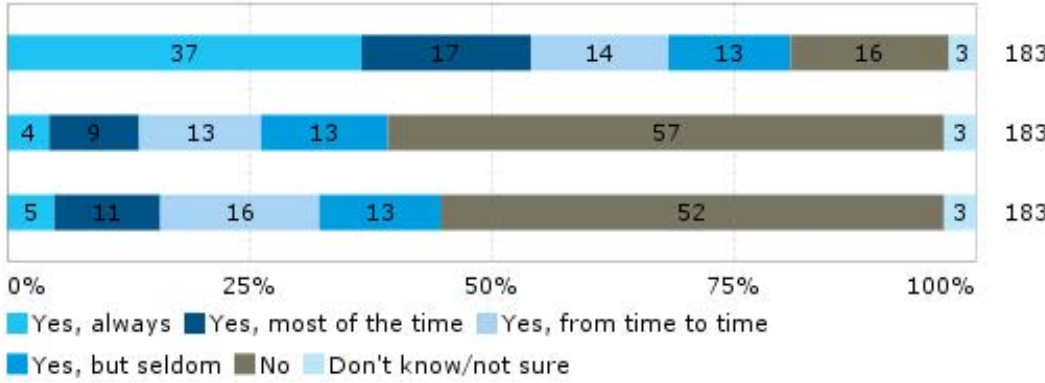

Figure 2. The extent to which the T1 and T1s students used the MCQ exercises, reflection exercises, and the follow-up materials. The statistics are based on 183 responses.

Furthermore, the survey revealed a diverse usage of the learning paths and showed that they provided a high degree of flexibility to the students with regards to time, place and pace of studying:

- $80 \%$ of the students most frequently used the learning paths at home, $13 \%$ used the materials at the university prior to/after teaching.

- $81 \%$ of the students most frequently used the learning paths alone, $19 \%$ together with peers.

- $39 \%$ of the students most frequently used the learning paths in the morning and afternoon, $14 \%$ in the evening on weekdays, during the weekend and other days off, $12 \%$ in the evening on weekdays. $29 \%$ stated that it varied. 
- The learning paths were most often used no earlier than one week prior to the related oncampus exercises $(51 \%)$ - typically on a specific day - or in the subsequent week $(24 \%)$. Only $4 \%$ used the learning paths earlier than one week prior to the related on-campus exercises.

- $48 \%$ of the students most frequently went through an entire learning path during one day. $21 \%$ went through minor parts from time to time. $16 \%$ went through more than one learning path during one day. $15 \%$ went through learning paths over more than one day.

- The webcasts had the second-most plays within one day just prior to the exam.

\section{Student Performance}

The student performance has been evaluated based on the examination results, the students' learning approach, and their perceived utility of the materials and online activities.

The passing rates and grade point-averages (GPA) for each of the tracks are listed in Table 2. The survey respondent results were calculated by obtaining the examination results of the respondents from each track and, in addition, examination results from all students enrolled in the module are listed as a reference. In comparison the GPA was 8.6 and pass rate $96 \%$ in 2012 and 8.9 and $96 \%$ in 2011. However, as the profile of the cohort and examination questions differs from year to year the grades fluctuate equally and, thus, cannot be used for comparison.

Table 2: The students' examination results with a comparison of pass rates and GPA for the online students (T1) and the face-to-face students (T2-4). The grades and percentages in brackets are the grades and rates when the mathematical students are deducted. The pass rates are calculated based on the students that are eligible to attend the examination (i.e. have passed 4 of the written assignments during the module) and have indeed attended it.

\begin{tabular}{|c|c|c|c|c|}
\hline $\begin{array}{l}\text { Survey } \\
\text { respondents }\end{array}$ & $\begin{array}{l}\text { Track 1: } \\
\text { online students } \\
(\mathrm{n}=99)\end{array}$ & $\begin{array}{l}\text { Track 1s: } \\
\text { switching students } \\
(\mathrm{n}=90)\end{array}$ & $\begin{array}{l}\text { Track 2-4: } \\
\text { face-to-face students } \\
(\mathrm{n}=122)\end{array}$ & \\
\hline GPA & $9.3(9.0)$ & $8.6(8.3)$ & $7.9(7.8)$ & \\
\hline Pass rate & $99 \%(98 \%)$ & $99 \%(99 \%)$ & $95 \%(95 \%)$ & \\
\hline $\begin{array}{l}\text { Absence, } \\
\text { missing } \\
\text { eligibility or sign } \\
\text { up. }\end{array}$ & 2 were absent & 1 was not eligible. & $\begin{array}{l}2 \text { were absent, } 1 \text { was not } \\
\text { eligible, } 1 \text { unknown status. }\end{array}$ & \\
\hline Entire cohort & $\begin{array}{l}\text { Track 1: } \\
\text { online students } \\
(n=306)\end{array}$ & & $\begin{array}{l}\text { Track } 2-4 \text { and T1s: face-to- } \\
\text { face and switching } \\
\text { students } \\
(n=795)\end{array}$ & All \\
\hline GPA & $9.1(n=253)$ & $\mathrm{n} / \mathrm{a}$ & $7.1(n=618)$ & 7.7 \\
\hline Pass rate & $97 \%$ (8 failed) & $\mathrm{n} / \mathrm{a}$ & $94 \%$ (35 failed) & $95 \%$ \\
\hline $\begin{array}{l}\text { Absence, } \\
\text { missing } \\
\text { eligibility or sign } \\
\text { up. }\end{array}$ & $\begin{array}{l}6 \text { were absent, } 17 \text { were not } \\
\text { eligible, } 16 \text { did not sign up, } \\
14 \text { results unavailable. }\end{array}$ & $\mathrm{n} / \mathrm{a}$ & $\begin{array}{l}26 \text { were absent, } 73 \text { were not } \\
\text { eligible, } 39 \text { did not sign up, } \\
39 \text { results unavailable. }\end{array}$ & $\begin{array}{l}\text { no data } \\
\text { available }\end{array}$ \\
\hline
\end{tabular}

The table shows significantly better examination results in T1 and T1s than T2-4. In particular the GPA shows a significant variation: the T1 students have the best score, the T1s the second best, and T2-4 the lowest score. Though the relative percentage of students studying Mathematics and Mathematics-Economics is higher in T1, the tendency is the same when these groups are deducted from the figures (shown in brackets). A similar pattern is present when European Journal of Open, Distance and e-Learning - Vol. 17 / No. 2 
looking at the examination results of all students enrolled in T1 and T2-4 (cf. Table 2 and Figure 3). Also the amount of top grades is significantly higher among the T1 students (cf. Figure 3).

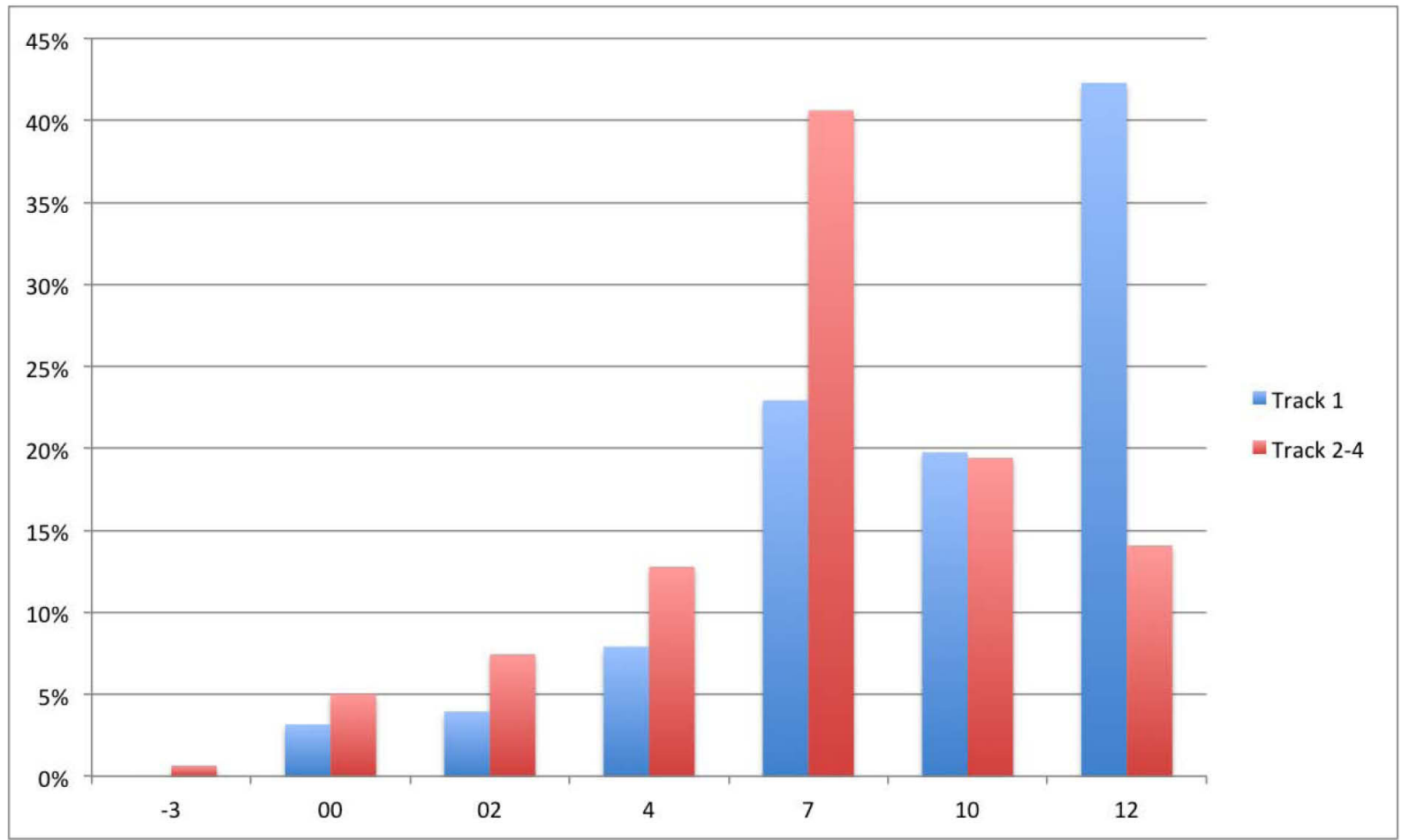

Figure 3. The relative grade distribution of the online students (T1) and the face-to-face students (T2-4) in percentages. Notice that the figures also include the mathematical students.

The survey also revealed that the students on T1 and T1s had varying perceptions of the utility of the learning paths suggesting different approaches to learning: strategic, surface, and deep learning. All three learning approaches were present and of rather comparable significance with a slight preference for using the learning paths for the strategic purpose 'doing a better exam' and least preference for 'understanding the topics in depth'.

I used the learning paths because I expected they would help me do a better exam.

I used the learning paths because I expected they would help me learn the most necessary curriculum.

I used the learning paths because I expected they would help me understand the topics of the module in depth.

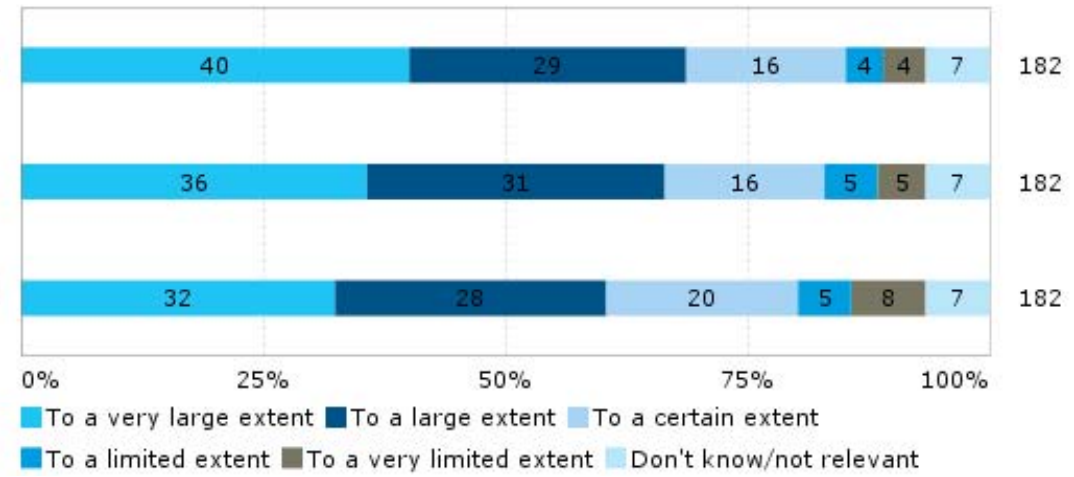

Figure 4. To what extent the students' found the three statements to be consistent with their use of the learning paths. 
The students perceived the webcasts and the MCQs as the most important online learning material for understanding the curriculum.

The videos

The MCQ exercises

The follow-up materials and videos

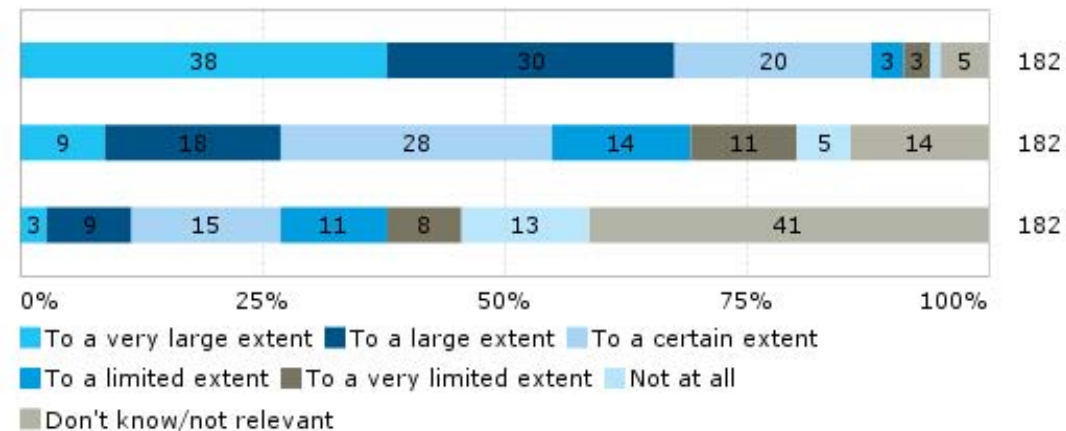

Figure 5. The students' assessment of the extent to which the different materials helped them understand the curriculum.

Only a minority of the students found the follow-up materials useful for understanding the curriculum and merely 79 students participated in the reflection exercises (which equals approximately $14 \%$ of all students who had accessed the learning paths). A few more had seen the follow-up materials. However, the 24 students who participated in half of the reflection exercises or more all passed their examination and obtained a GPA of 11.1.

\section{Student Satisfaction, Preferences, and Perceived Utility}

The survey shows a significantly higher satisfaction between the T1 and T1s students than the T2-4 students (cf. Table 3). In addition, the vast majority of the students using the learning paths preferred learning paths to face-to-face lectures (cf. Figure 6).

Table 3: The student satisfaction with the learning outcome of the module and preferences for faceto-face lectures versus online learning paths. The figure in brackets shows the satisfaction among non-mathematics/mathematics-economics students. $2 \%$ of the respondents $(n=5)$ decided to stop or switch track during the module and thus deducted from the figures.

\begin{tabular}{|l|l|l|l|}
\hline & $\begin{array}{l}\text { Track 1: } \\
\text { online students } \\
(n=99,31 \%)\end{array}$ & $\begin{array}{l}\text { Track 1s: } \\
\text { switching students } \\
(\mathrm{n}=90,28 \%)\end{array}$ & $\begin{array}{l}\text { Track 2-4: } \\
\text { face-to-face students } \\
(\mathrm{n}=122,39 \%)\end{array}$ \\
\hline $\begin{array}{l}\text { Prefers or highly prefers learning } \\
\text { paths }\end{array}$ & $63 \%$ & $67 \%$ & $\mathrm{n} / \mathrm{a}$ \\
\hline $\begin{array}{l}\text { Prefers or highly prefers face-to- } \\
\text { face lectures }\end{array}$ & $28 \%$ & $12 \%$ & $\mathrm{n} / \mathrm{a}$ \\
\hline $\begin{array}{l}\text { Satisfied or highly satisfied with } \\
\text { the learning outcome }\end{array}$ & $83 \%(80 \%)$ & $76 \%$ & $52 \%$ \\
\hline
\end{tabular}


Highly prefers learning paths

Prefers learning paths

No preference

Prefers face-to-face lectures

Highly prefers face-to-face lectures

Don't know

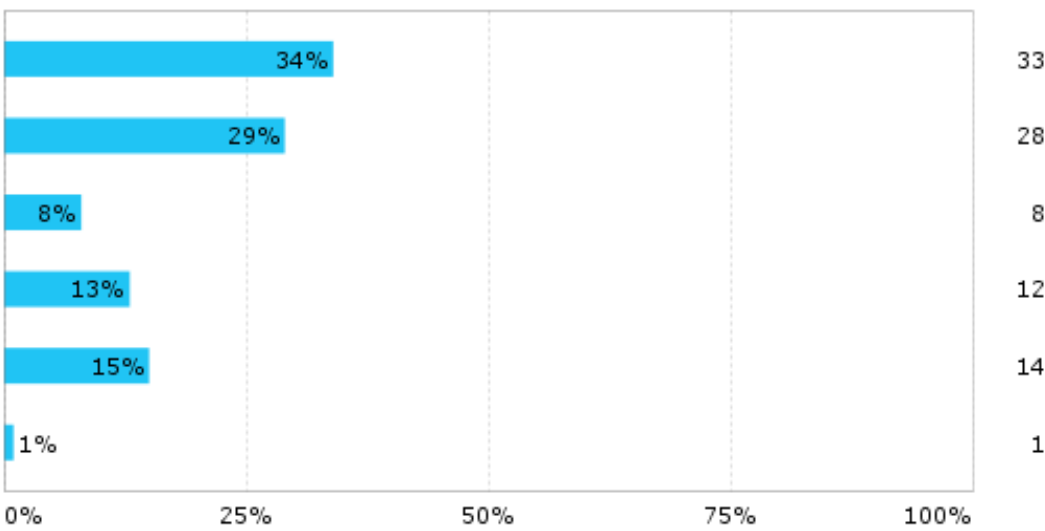

Figure 6. Whether the online students (T1) prefer learning paths similar as in Calculus 2 or traditional face-to-face lectures in an auditorium.

In addition, the students were asked to further elaborate their preferences. The majority of the group of students who preferred learning paths highlighted the flexibility as particular satisfying, including that they could decide the pace of the presentation of the curriculum, and that they could repeat difficult passages and skip the easy parts. The students were highly satisfied with the way the learning paths were designed, especially the short webcasts and exercises. This is, among others, expressed in these responses:

'The learning paths provide an excellent opportunity for me to administer the pace of the lecture, which highly helps me to increase my understanding' (student $A$, translated from Danish)

'... the videos makes it much easier to keep up and understand the curriculum, as you can spend the time you need to go back, repeat a section, to cover it all. In the lectures the lecturer may have to burry up if there is limited time left. Large cadean to ... for being very clear and have a good pace in the videos' (student B, translated from Danish)

The more sceptical students expressed, among others, the need for self-discipline:

'Personally I bighly appreciate the lectures as my self discipline is not very bigh, but during the examination preparation the learning paths were very belpful.' (student $C$, translated from Danish)

A frequent comment was that the students saw the webcasts in their study groups where they helped each other with questions and understanding. Thus, some students found it important to form such groups prior to being introduced to this kind of teaching.

Furthermore, the students in $\mathrm{T} 1$ and $\mathrm{T} 1 \mathrm{~s}$ were asked to indicate their perceived utility of the learning paths for different purposes on a likert scale (cf. Figure 7). 
Learning the curriculum

Repetition during the module

Exam preparation

Solving assignments

Providing perspective

Later in the programme

Later employment

Reexam preparation

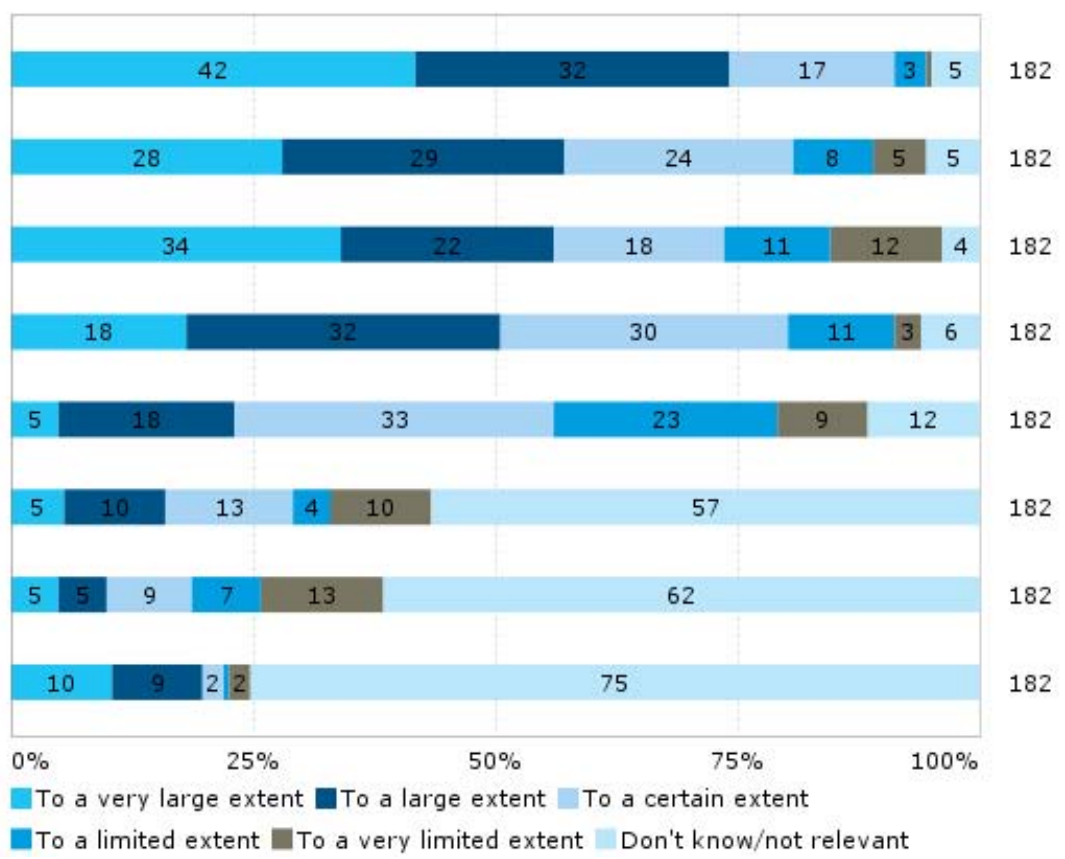

Figure 7. The students' perception of the utility of the learning paths for different purposes

The students found the learning paths particularly useful for learning the curriculum, for repetition during the module, for examination preparation, and for solving assignments; however, a few of the students could also see the utility of the materials for providing perspective, for later employment, and for later during their education though these options were hypothetical at this point.

\section{Learning Design for Educational Development}

The results suggest that a simple transformation comprising webcasts and MCQs combined in learning paths can be used to improve science teaching in terms of higher student performance, higher student satisfaction, and more flexible learning in a feasible way. The pivotal questions are, however, whether these positive and unequivocal results can be recreated when teaching is being transformed in a comparable setting, and whether a learning design model such as STREAM can be used for this matter. One cannot say for sure based on this transformation, but considering the unambiguity and significance of the results and the rather common setting and simple learning design, the design and results should be transferrable to other contexts. In addition, the first results of a more recent (i.e. 2014) transformation of the Calculus 1 module by means of an almost identical learning design indicates that a this new group of students share the same preference for online learning with learning paths and makes use of the flexibility. The preliminary results of the survey reveal that the majority of the students prefer learning paths to face-to-face lectures, that they most frequently use the learning paths other places than at the university, and that they mostly access the materials at other times than regular teaching hours or at very different times.

Naturally, face-to-face lectures can take many forms and may for instance entail engaging and active learning. In such cases, replacing the face-to-face lectures with webcasts and MCQs may be considered a step backwards. On the other hand, this transformation was only guided by the STREAM model and, as such, potentially disregarding important pedagogically points and thus missing out on some of its potential. The experiences from this transformation suggests that it can be very difficult to predict how a teacher will adopt a learning design model and as such how the teaching will be transformed and carried out. So a big imponderable in this kind of 
educational development is the actual adoption of the learning design model. As stressed by Conole and others learning design aims at making theory-informed pedagogical decisions, not necessarily prescribing the teaching in every detail (Conole \& Fill, 2005; Conole \& Oliver, 2002). Following this idea, the fact that the STREAM model did influence some aspects of the transformation can be considered as appropriate use. However, half uptakes make it difficult to identify the potential of learning design for educational development. As a consequence more research on how learning design models and tools are deployed and actually adopted by teachers and in teaching practice would be useful. Potentially, a properly deployed learning design model could serve as a tool for recreating successful educational interventions.

\section{Conclusions and Perspective}

Though this study entails certain statistical uncertainties and other threats to validity, all the results suggest the same thing unanimously: transforming a traditional science module of calculus into blended learning with a simple learning design replacing the face-to-face lectures with webcasts and online activities in terms of MCQs and reflection exercises has the potential to improve teaching and learning in several ways. The online students obtained significantly better examination results, better pass rates, and were significantly more satisfied with the learning compared to the face-to-face students. In addition, $63 \%$ of online students preferred the online learning with learning paths to traditional face-to-face lectures. Only $28 \%$ preferred the traditional face-to-face lectures.

There was evidence of highly flexible learning in terms of a very diverse use and access to the materials. The learning paths were used at different locations and $80 \%$ of the students most frequently used them at home in spite of that the vast majority lived less than 10 kilometres away from campus. $51 \%$ of the students most frequently used the learning paths within a week prior to the related on-campus exercises; however, the way the paths were used was highly diverse ranging from $21 \%$ who most frequently was going through minor parts from time to time to $16 \%$ who studied more than one learning path per day. Also, the materials were used intensively just prior to the examination suggesting a high degree of use for repetition. Only few students expressed concerns with the online materials and were worried that they would not have the self-discipline to use the learning paths; however, the majority of students found the materials useful for not only for learning the curriculum but also for repetition during the module, examination preparation, and solving assignments.

With regards to the desire of the management to make the teaching more cost-effective by reducing the teaching staff and at the same time modernise the teaching practice and improve learning, the transformation must be considered successful. The learning did improve and the marginal costs for developing the online learning was less than 5 EUR per student and the variable costs for repeating the online learning would be approximately 1 EUR per student. Significantly lower than the face-to-face setup with its required teaching staff and lecture halls. However, to get a complete picture of the costs the fixed costs for running the media lab and the educational unit must be taken into account as well.

In addition, this study provides provisional evidence of some of the potential of blended learning and pointers to how it can be actualised. Among others, the study revealed that blended learning based on a simple learning design where traditional face-to-face science lectures are completely replaced with online learning in terms of webcasts and activities has the potential to increase flexibility for the students, improve examination results, and increase student satisfaction. Compared to other studies such as Price and Kirkwood's review of evidence-based practices of technology-enhanced learning in higher education (2011) and the 'Program in Course Redesign' by the National Center for Academic Transformation (Twigg, 2009; 2013) this study may serve as 
an example of how technology for blended learning can be used to support flexibility, support mobile and geographically remote learners, support feedback to students, support students' revision and reinforcement, increase student satisfaction, and reduce costs (Price \& Kirkwood, 2011, pp.3-4; Twigg, 2009, p.1148). This may, at the same time, be seen as a break with the perception that 'no two blended learning designs are identical' (Garrison \& Kanuka, 2004, p.97) and that different contexts necessarily require a unique blended learning design (ibid.). The study illustrates that developing and implementing blended learning does not always have to be a complex and daunting affair with comprehensive teacher training and thorough pedagogical strategies and/or radical change of teaching approach to yield good results. And though some effort is required to do the actual transformation and to keep the module up-to-date, the case provided in this article suggests that learning design has the potential to facilitate good practice and even address some of the grand challenges in science education and the current political agenda of providing higher education to large groups of students. Or to put this in other words: learning design may help 'breaking the iron triangle'; i.e. widen access, improve quality, and lower costs at the same time (cf. Daniel et al., 2009). It may even clear the way for transforming education into completely online and open learning.

\section{Future Work}

The fact that learning did improve in so many aspects in spite of the simple learning design and the deficient adoption of the STREAM model suggests that educational technology has the potential to transform and improve learning in similar large-scale science modules in a feasible way and that learning design may be an important tool to actually make it feasible. As a consequence future research within this field should concentrate on at least two aspects: developing and optimising operational and efficient learning design tools for guiding the transformation and using educational technology in science higher education, and scrutinising how learning design and design models are actually adopted and develop methods for improving the deployment and adoption. In addition, the future work includes transforming other parts of the module, such as the examination, into online learning.

\section{References}

1. Aarhus Universitet (2011). Den Faglige Udviklingsproces. Øurige bilag. Universitetsledelsen den. 9. marts. Retrieved July 2, 2014 from http://medarbejdere.au.dk/fileadmin/res/fau/dok/fau_bilag_oevrige_bilag_090311.pdf.

2. Blumenfeld, P.C.; Soloway, E.; Marx, R.W.; Krajcik, J.S.; Guzdial, M.; Palincsar, A. (1991). Motivating project-based learning: Sustaining the doing, supporting the learning. In Educational psychologist, 26(3-4), (pp. 369-398).

3. Bonwell, C.C. and Eison, J.A. (1991). Active learning: Creating excitement in the classroom. Washington, DC: School of Education and Human Development, George Washington University.

4. Britain, S. (2004). A review of learning design: concept, specifications and tools. A report for the JISC E-learning Pedagogy Programme, 2006.

5. Brown, A.L. (1992). Design experiments: Theoretical and methodological challenges in creating complex interventions in classroom settings. In The journal of the learning sciences, 2(2), (pp. 141-178).

6. Conole, G. (2013). Designing for learning in an open world. New York: Springer.

7. Conole, G. and Dyke, M. (2004). What are the affordances of information and communication technologies? In Association for Learning Technology Journal, 12(2), (pp. 113-124). 
8. Conole, G.; Dyke, M.; Oliver, M. and Seale, J. (2004). Mapping pedagogy and tools for effective learning design. In Computers \& Education, 43(1), (pp. 17-33).

9. Conole, G. and Fill, K. (2005). A learning design toolkit to create pedagogically effective learning activities. In Journal of Interactive Media in Education, 2005(1).

10. Conole, G. and Oliver, M. (2002). Embedding theory into learning technology practice with toolkits. In Journal of Interactive Media in Education, 2002(1).

11. Correll, A. (2014). Godt studiemiljo kan stadig forbedres. Retrieved from http://newsroom.au.dk/nyheder/vis/artikel/godt-studiemiljoe-kan-stadig-forbedres/.

12. Course Catalogue (2013). Calculus 2 (Q2) - Search Course. Retrieved March 04, 2014 from http://kursuskatalog.au.dk/en/coursecatalog/Course/show/41378/.

13. Creswell, J.W. (2014). Educational Research: Planning, Conducting and Evaluating Quantitative and Qualitative Research. Fourth Edition. Essex: Pearson Education Limited.

14. Cross, S. and Conole, G. (2009). Learn about learning design. Part of the OU Learn about series of guides. The Open University: Milton Keynes. Retrieved from http://www.open.ac.uk/blogs/OULDI/wp-content/uploads/2010/11/Learn-aboutlearning-design_v7.doc.

15. Daniel, J.; Kanwar, A. and Uvalić-Trumbić, S. (2009). Breaking higher education's iron triangle: Access, cost, and quality. In Change: The Magazine of Higher Learning, 41(2), (pp. 30-35).

16. The Danish Government (2012). Danmark i arbejde - udfordringer for dansk okonomi mod 2020. Retrieved from http://www.stm.dk/multimedia/danmark_i_arbejde__udfordringer_for_dansk_konomi_mod_2020_web.pdf.

17. The Danish Ministry of Education (2014a). Andel af en årgang der forventes at få en uddannelse Undervisningsministeriet. Retrieved from http://uvm.dk/Service/Statistik/Tvaergaaendestatistik/Andel-af-en-aargang-der-forventes-at-faa-en-uddannelse.

18. The Danish Ministry of Education (2014b). Metode bag fremskrivning af en ungdomsairgangs uddannelsesniveau samt deres tidsforbrug. Retrieved from

http://uvm.dk/ /media/UVM/Filer/Stat/PDF14/140321\%2014022014Metode $\% 20 \mathrm{bag} \% 2$ Oprofilmodellen_ny.ashx.

19. Earle, R.S. (2002). The integration of instructional technology into public education: Promises and challenges. In Educational Technology, 42(1), (pp. 5-13).

20. Garrison, D.R. and Kanuka, H. (2004). Blended learning: Uncovering its transformative potential in higher education. In The internet and higher education, 7(2), (pp. 95-105).

21. Godsk, M. (2013). STREAM: a Flexible Model for Transforming Higher Science Education into Blended and Online Learning. In T. Bastiaens \& G. Marks (eds.), Proceedings of World Conference on E-Learning in Corporate, Government, Healthcare, and Higher Education 2013, (pp. 722728). Chesapeake, VA: AACE.

22. Godsk, M. (2014). Efficient Learning Design-Concept, Catalyst, and Cases. Ascilite 2014: Rhetoric and Reality: Critical perspectives on educational technology, Dunedin, New Zealand, 23-26 November.

23. Hines, P.J.; Mervis, J.; McCartney, M.; Wible, B. (eds). (2013). Grand challenges in science education. Science, (p. 340).

24. Jones, S.R. (1992). Was there a Hawthorne effect? In American Journal of Sociology.

25. Mazur, E. and Hilborn, R.C. (1997). Peer instruction: A user’s manual. In Physics Today, 50(4), (pp. 68-69). 
26. Novak, G.M.; Patterson, E.T.; Gavrin, A.D.; Christian, W. (1999). Just-in-Time Teaching: Blending Active Learning with Web Technology. Upper Saddle River, NJ: Prentice Hall.

27. Price, L. and Kirkwood, A. (2011). Enhancing professional learning and teaching through technology: a synthesis of evidence-based practice among teachers in higher education. The Open University. Retrieved from

http://www.lth.se/fileadmin/lth/genombrottet/DTR/PLATP_Main_Report_2011.pdf.

28. Romiszowski, A.J. (2004). How's the e-learning baby? Factors leading to success or failure of an educational technology innovation. In Educational Technology, 44(1), (pp. 5-27).

29. Simkins, S.P. and Maier, M.H. (eds.) (2010). Just-in-Time Teaching: Across the Disciplines, and Across the Academy. Sterling: Stylus Publishing, LLC.

30. Twigg, C. (2009). Improving Learning and Reducing Costs for Online Learning. In P.L. Rogers, G.A. Berg, J.V. Boettcher, C. Howard, L. Justice \& K. Schenk (eds.), Encyclopedia of Distance Learning, (pp. 1148-1154), Second Edition. Hershey: IGI Global.

31. Twigg, C. (2013). An overview of course redesign. The National Center for Academic Transformation. Retrieved from http://www.thencat.org/Articles/An Overview of Course Redesign.pdf

32. Weller, M. (2002). Delivering learning on the Net: The why, what \& how of online education. London: RoutledgeFalmer.

\section{Acknowledgements}

Special thanks to Camilla Bundgaard Løve and Jesper Strøm Søhof for help with data collection and transcription, Christian Dalsgaard for comments on the survey, Charlotte Overgaard and Søren Anker Andersen for help with obtaining data, Klaus Thomsen, Cecilie Kjer, and Science Media Lab for the development of the materials, and Elin Sørensen for proofreading 